\title{
ESTABILIDADE TÉRMICA DE BACTERIOCINA PRODUZIDA POR Lactobacillus sakei
}

\author{
CONTESSA, C. R. ${ }^{1}$, SOUZA, N. B. ${ }^{1}$, GONÇALO, G. B. ${ }^{1}$, ALMEIDA, L. ${ }^{1}$, MANERA, A. \\ P. ${ }^{1}$, MORAES, C. C. ${ }^{1}$ \\ ${ }^{1}$ Universidade Federal do Pampa (UNIPAMPA) - Bagé - RS - Brasil \\ E-mail para contato: camilaramao@hotmail.com
}

\begin{abstract}
RESUMO - Alguns dos peptídeos biologicamente ativos, conhecidos como bacteriocinas, são secretados a partir de bactérias e fungos, dentre os organismos produtores de bacteriocinas, destacam-se as bactérias ácido láticas. Neste trabalho objetivou-se avaliar a resistência térmica da bacteriocina produzida por Lactobacillus sakei, previamente isolado pelo grupo de trabalho, através de análise antimicrobiana frente aos patógenos Staphylococcus aureus e Escherichia coli. O desenvolvimento do Lactobacillus deu-se em caldo MRS a $32^{\circ} \mathrm{C}$ por $12 \mathrm{~h}$. $\mathrm{O}$ caldo fermentado contendo a bacteriocina foi centrifugado, obtendo assim o extrato livre de células (ELC). O ELC foi submetido as temperaturas de $40^{\circ} \mathrm{C}, 60^{\circ} \mathrm{C}, 80^{\circ} \mathrm{C}$ e $100^{\circ} \mathrm{C}$ por $24 \mathrm{~h}$ em estufa e processo de esterilização a $121^{\circ} \mathrm{C}$ em autoclave por $15 \mathrm{~min}$. Após, os extratos foram submetidos a análise antimicrobiana pelo método de microplacas. Obteve-se com os resultados uma porcentagem em torno de $100 \%$ de inibição contra os micro-organismos testados nas temperaturas de $40^{\circ} \mathrm{C}, 60^{\circ} \mathrm{C}, 80^{\circ} \mathrm{C}$ e na temperatura de esterilização, havendo um decréscimo na temperatura de $100^{\circ} \mathrm{C} / 24 \mathrm{~h}$, porém apresentando ainda um alto potencial de inibição. Concluise que a bacteriocina produzida por Lactobacillus sakei possui um alto poder antimicrobiano, bem como estabilidade térmica nas temperaturas analisadas, constatando assim sua possível aplicabilidade como conservante natural em produtos alimentícios submetidos a tratamentos térmicos.
\end{abstract}

\section{INTRODUÇÃO}

Bacteriocinas são peptídeos biologicamente ativos, obtidos através de bactérias e fungos, que são sintetizados ribossomicamente (ROSA, 2001). Bactérias ácido láticas (BAL) têm mostrado um alto potencial de produção destes peptídeos, sendo o gênero Lactobacillus um dos mais importantes pois apresenta espécies com propriedades bioquímicas e fisiológicas muito diferentes (VÁSQUEZ, et al., 2009), dentre essas tem-se o Lactobacillus sakei, caracterizado pela produção de bacteriocinas potencialmente ativas contra o desenvolvimento de micro-organismos patógenos (ROSA, 2001).

A produção de bacteriocinas está relacionada com estratégia competitiva das bactérias produtoras contra outras bactérias, permitindo assim uma maior disponibilidade de nutrientes no meio para seu desenvolvimento. Esta produção ocorre na fase logarítmica do crescimento 
microbiano ou no final desta e início da fase lag, essas possuem uma ação inibitória contra outras bactérias, podendo assim serem utilizadas como conservantes naturais já que o processo ocorre de forma espontânea (LOUREIRO, 2015).

Com o desenvolvimento de produtos industrializados tem-se a necessidade de garantir um alimento seguro e de qualidade ao consumidor, sendo que as tecnologias de conservação usadas atualmente não garantem integralmente sua segurança, havendo a necessidade do desenvolvimento de alternativas eficientes para a conservação desses (OLIVEIRA et al., 2012). Bacteriocinas quando usadas juntamente com outros tratamentos disponíveis têm efeito sinergista como barreira do desenvolvimento de patógenos, promovendo assim a seguridade dos alimentos (MELO et al., 2005).

Durante o armazenamento de alguns produtos com alta perecibilidade ocorre a alteração de suas características, ocasionado por influência de fatores intrínsecos e extrínsecos (MARTINS et al.,2011). Para que estes produtos tenham estabilidade garantida precisam ser submetidos a tratamentos térmicos e/ou a adição de conservantes, onde que a escolha desse deve ser baseada no seu espectro antimicrobiano, condições de armazenamento e estabilidade térmica, pois devem permanecer ativos após o processo (EDITORA INSUMOS, 2009).

Neste contexto objetivou-se avaliar a termorresistência da bacteriocina produzida por Lactobacillus sakei, isolado pelo grupo de pesquisa a partir de salame italiano, através de análise antimicrobiana frente a Staphylococcus aureus e Escherichia coli.

\section{METODOLOGIA}

\subsection{Obtenção do extrato livre de células}

Utilizou-se de cepa de Lactobacillus sakei criopreservada a $-14^{\circ} \mathrm{C}$, previamente isolada de salame italiano pelo grupo de estudos. A preparação do inóculo deu-se a partir do desenvolvimento da cultura em caldo MRS (Lactobacillus MRS Broth), a temperatura de $32^{\circ} \mathrm{C}$ por $12 \mathrm{~h}$. A propagação do inóculo foi feita no mesmo caldo e temperatura a uma agitação de $150 \mathrm{rpm}$ por mais $12 \mathrm{~h}$. O fermentado foi então centrifugado a $4^{\circ} \mathrm{C}$ e $5500 \mathrm{rpm}$ por $15 \mathrm{~min}$, para que se obtivesse o extrato livre de células.

\subsection{Tratamentos}

$\mathrm{O}$ extrato livre de células foi acondicionado em recipiente fechado para que não houvesse evaporação e então submetido às temperaturas de $40,60,80$ e $100^{\circ} \mathrm{C}$ por $24 \mathrm{~h}$ em estufa, bem como a temperatura de esterilização sendo essa $121^{\circ} \mathrm{C}$ por $15 \mathrm{~min}$ (em autoclave).

\subsection{Análise antimicrobiana}

Foram então realizados testes antimicrobianos destes extratos tratados termicamente e do extrato livre de células sem tratamento térmico sob micro-organismos patogênicos comumente encontrados na indústria de alimentos como Staphylococcus aureus ATCC® (12598) e Escherichia coli ATCC $®$ (11229). As análises foram realizadas pelo método de microplacas descrito na metodologia na NCCLS (2003), a microplaca utilizada contém 96 poços com capacidade de $400 \mu \mathrm{L}$ cada, onde foram adicionados caldo adequado ao 
desenvolvimento da microbiota utilizada, os extratos submetidos a tratamentos térmicos, bem como o extrato bruto para posterior comparação e a microbiota utilizada.

As leituras foram realizadas em absorvância com comprimento de onda de $630 \mathrm{~nm}$ em leitora de microplacas no tempo 0 e $16 \mathrm{~h}$. Os resultados foram expressos em porcentagem de inibição através da comparação do branco (caldo + cultura) com os poços contendo extrato.

\section{RESULTADOS E DISCUSSÃO}

Pode-se através da Tabela 1 observar os resultados obtidos para a inibição dos microorganismos testados a partir da exposição do extrato a diferentes temperaturas, bem como, do extrato livre de células sem ter passado por tratamento térmico.

Tabela 1: Porcentagem de inibição do extrato quando submetido a diferentes temperaturas

\begin{tabular}{lcccccc}
\hline \multicolumn{6}{c}{ Tratamentos } \\
\hline & $\begin{array}{c}\text { Sem } \\
\text { tratamento } \\
\text { térmico }\end{array}$ & $40^{\circ} \mathrm{C} / 24 \mathrm{~h}$ & $60^{\circ} \mathrm{C} / 24 \mathrm{~h}$ & $80^{\circ} \mathrm{C} / 24 \mathrm{~h}$ & $100^{\circ} \mathrm{C} / 24 \mathrm{~h}$ & $121^{\circ} \mathrm{C} / 15 \mathrm{~min}$. \\
\hline $\begin{array}{c}\text { Staphylococcus } \\
\text { aureus }\end{array}$ & $100 \pm 2,37^{\mathrm{a}}$ & $100 \pm 0,50^{\mathrm{a}}$ & $100 \pm 0,11^{\mathrm{a}}$ & $99,57 \pm 1,39^{\mathrm{a}}$ & $86,48 \pm 2,17^{\mathrm{b}}$ & $98,99 \pm 1,29^{\mathrm{a}}$ \\
\hline Escherichia coli & $100 \pm 4,78^{\mathrm{a}}$ & $97,75 \pm 0,03^{\mathrm{a}}$ & $100 \pm 0,95^{\mathrm{a}}$ & $97,49 \pm 1,44^{\mathrm{a}}$ & $80,26 \pm 2,65^{\mathrm{b}}$ & $96,87 \pm 1,63^{\mathrm{a}}$ \\
\hline Valores seguidos por mesma letra na mesa linha não diferem estatisticamente entre si para o nível de significância de $95 \%$.
\end{tabular}

Pode-se constatar que o extrato se comporta estatisticamente de mesma forma quando submetido às temperaturas de $40^{\circ} \mathrm{C}, 60^{\circ} \mathrm{C}, 80^{\circ} \mathrm{C}$ e $121^{\circ} \mathrm{C}$ quando testado sob os dois microorganismos analisados, resultando em aproximadamente $100 \%$ de inibição da microbiota testada, apresentando um decaimento na inibição quando submetido a temperatura de $100^{\circ} \mathrm{C}$, porém continua sendo um antimicrobiano com alto potencial nesta condição.

A diminuição na inibição para a temperatura de $100^{\circ} \mathrm{C}$ pode ser explicada pelo tempo que a bacteriocina ficou exposta a esta temperatura $(24 \mathrm{~h})$, resultando em uma degradação parcial do composto, já para a temperatura de $121^{\circ} \mathrm{C}$ a inibição foi próxima a $100 \%$, tendo em vista que o tempo de exposição foi de apenas 15 min, não sendo suficiente para causar a degradação da bacteriocina embora a temperatura seja superior a $100^{\circ} \mathrm{C}$. Este resultado é interessante do ponto de vista tecnológico, já que $121^{\circ} \mathrm{C}$ é a temperatura de esterilização de alguns produtos alimentícios.

Tendo em vista o tempo de exposição às temperaturas analisadas, pode-se constatar que a bacteriocina produzida por Lactobacillus sakei possui um alto potencial para aplicação em alimentos processados com altas temperaturas e um tempo longo de exposição.

Os resultados encontrados foram de acordo aos de Camargo (2011), que obteve em seu estudo estabilidade térmica de bacteriocinas obtidas de isolados de amostra de mortadela quando submetidos às temperaturas de $4^{\circ} \mathrm{C}, 25^{\circ} \mathrm{C}, 30^{\circ} \mathrm{C}, 37^{\circ} \mathrm{C}, 45^{\circ} \mathrm{C}, 60^{\circ} \mathrm{C}, 80^{\circ} \mathrm{C}$ e $100^{\circ} \mathrm{C}$ por $2 \mathrm{~h}$. Loureiro (2015) também constatou estabilidade térmica da bacteriocina produzida por 
Lactobacillus plantarum $\mathrm{B} 39$ quando submetida às temperaturas de $4{ }^{\circ} \mathrm{C}, 22^{\circ} \mathrm{C}, 37^{\circ} \mathrm{C} \mathrm{e} 44^{\circ} \mathrm{C}$ durante 44 dias.

\section{CONSIDERAÇÕES FINAIS}

Pode-se concluir que a bacteriocina produzida por Lactobacillus sakei, possui alto potencial antimicrobiano frente a Escherichia coli e Staphylococcus aureus, bem como resistência térmica por $24 \mathrm{~h}$ nas condições analisadas e estabilidade na condição de esterilização, constata-se assim, a possível aplicabilidade da utilização desta em produtos alimentícios submetidos a tratamentos térmicos, necessitando de estudos relacionados a aplicação desta bacteriocina em alimentos, etapa que procederá a esta no desenvolvimento do projeto.

\section{AGRADECIMENTOS}

A FAPERGS, pelo apoio financeiro e incentivo a pesquisa e ao Laboratório de Microbiologia e Toxicologia de Alimentos pelo espaço físico.

\section{REFERÊNCIAS}

CAMARGO, R. G. Ação de bacteriocinas de bactérias láticas no controle de Listeria monocytogenes e no aumento de vida de prateleira de mortadela fatiada. Tese de Doutorado, Universidade Federal de São Paulo, 2011.

EDITORA INSUMOS (2009). Conservação de alimentos por aditivos químicos. Disponível em: http://insumos.com.br/aditivos_e_ingredientes/materias/125.pdf. Acesso em: 21 fev. 2017.

LOUREIRO, D. S. P. M. Estudos da bacteriocina produzida por Lactobacillus plantarum B391 para potencial utilização na Indústria. Defesa de Mestrado, Instituto politécnico de Viana do Castelo, 2015.

LOUREIRO, D. S. P. M. Estudos da bacteriocina produzida por Lactobacillus plantarum B391 para potencial na indústria. Defesa de mestrado, Instituto Politécnico de Viana do Castelo, 2015.

MARTINS, G. A. S. FERRUA, F. Q. MESQUITA, K. S. BORGES, S. V. CARNEIRO, J. D. S. Estabilidade de doces em massa de banana prata. Rev Inst Adolfo Lutz. 70(3):332-40, 2011.

MELO, N. R. SOARES, N. D. F. GONÇALVES, M. P. J. Nisina: um conservante natural para alimentos. Revista Ceres, 52(303):921-938, 2005.

NCCLS: Metodologia dos testes de sensibilidade a agentes antimicrobianos por diluição para bactéria de crescimento aeróbico: Norma Aprovada - Sexta Ed.; v. 23, nº. 2, 2003. 
OLIVEIRA, C. P. SIQUEIRA, J. P. J. SILVA, J. A. Bacteriocinas como alternativa na conservação de alimentos. Revista Verde (Mossoró -RN -Brasil) v.7, n.1, p. 09-15, 2012.

ROSA, M. R. Purificação e mecanismo de ação de uma bacteriocina produzida por Lactobacillus sake $2^{a}$ isolado de linguiça frescal. Tese de Doutorado, Universidade de São Paulo, 2001.

VÁSQUEZ S. M. M. SUÁREZ, H. M. ZAPATA, S. B. Utilización de sustancias antimicrobianas producidas por bacterias ácido lácticas en la conservación de la carne. Rev. Chil. Nutr. V.36 n.1, 2009. 